\title{
THE EXPERIENCE OF TRAINING EXPERTS IN PUBLIC ADMINISTRATION AND DECISION-MAKING FIELDS ${ }^{1}$
}

\section{Kostiuk T. O.}

\section{INTRODUCTION}

Nowadays many societies and countries are becoming more and more focused on themselves as the backlash against globalization. On the contrary educational field strives to unification and generalization. The main vectors on which the modern international component of higher education develops is, firstly, the unification of scientific and pedagogical efforts and resources, and secondly, academic mobility and programs of double diplomas. The greatest success is observed in educational field demonstrating harmonic combination of outstanding national traditions and scientific schools' approaches with the world trend toward internationalization. Internationalization of higher education (IHE) has become a world trend, a fashionable movement with its rules, pros and cons revealing permanently in a different manner making challenge or even trouble. Some high schools consider this process as a way to economic upraising through foreign students studying/teaching and grants, the others - as a way to make scientists work out common demands, approaches and quality assurance in all educational fields. State policy of Ukraine, including educational field, is constantly aimed at achieving world standards for the sake of joining democratic developed countries and shared future in a fractured world.

IHE is now a fashionable buzzword and at the national, sectoral and institutional levels makes the functions and mechanism of providing educational services acquire an international character. At present, all over the world the internationalization of education is becoming an object and subject of a purposeful State policy, aimed at solving

1 This research is fulfilled in framework of Jean Monnet educational module "State-international-public: European values and norms determining interdisciplinary university module (STIPENDIUM)" № 611217-EPP-1-2019-1-UAEPPJMOMODULE with the support of the Erasmus+ Programme of the European Union.
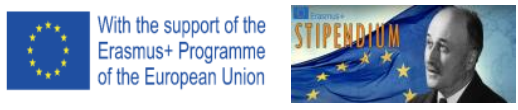
educational, institutional, political, social and economic problems. As well we might conceive national peculiarities and in what ways they remain a differentiating component of higher education institutions and, particularly, how it may help distinguish approaches to internationalization.

To reveal and to discuss multiple definitions, terms and approaches to internationalization present in literature and higher education practice would go far beyond the scope of this article. Accordingly, the controversy and effect of internationalization, seen through the lens of regional perception peculiarities, threats and opportunities, are of central interest.

But internationalization is nor only about and for higher education. International component is nowadays present in all spheres of social life and its damaging and threatening trends in one field can appear useful and progressive in another one. It's the matter of conscious and mature approaches to administering and governance. Europe has been trotting this way for a long time, while Ukraine is just starting. Our country suffers of the lack of qualified politicians, educators, managers and public administrators in all the fields; of the lack of will to adopt and to implement progressive European experience in educating new generation preserving societal values while trying some trans-internationalization. State policy of Ukraine is constantly aimed at achieving European standards. We are deeply convinced that before to elaborate and to implement right decisions at the highest level there is a need to educate a new generation of adequate policymakers and public administrators in the most vital spheres. Since there is a need of educational courses dealing specifically with European Union studies and issues.

International educational projects, international exchange programs, grant programs contribute to the development of an international component of training of specialists without physically crossing the border. That is what they call "internationalization at home". The Erasmus+ Jean Monnet Module "State-international-public: European values and norms determining interdisciplinary university module (STIPENDIUM)" proves advantages of the EU funding programs which are both pushing research and enabling the promotion of European integration ideas among $\mathrm{PhD}$ students, with a particular focus on the multidimensionality of modern day tasks for nation-states, the importance of an effective teaching of future public administrators, politicians and managers. Thus, it seems obvious that qualitative education for future specialists in public administration is not possible without IHE participation, especially in developing countries where the students' financial abilities are low which hinder long-term training abroad. 
The main categories for the comprehensive analysis of IHE trends are the national and supranational structures and the principles of interaction at all levels. Hence there is a need for a thorough study of ideas, principles, forecasting of priorities, internationalization of education policy in world, regional and national dimensions. It is also worth to determine the specificity of the IHE in different regions and states and to track the corresponding activity of educational institutions, students and teachers. Equally important is to monitor the application areas of international cooperation. All these aspects have been examined and set forth in this article.

The article first examines IHE proceeding from its provenance and generally accepted growing role in higher education. It further questions how IHE correlates, influences or depends on the globalization, multiculturalism, political vectors and national identity and academic traditions. Above all the article argues that IHE only strives to enrich and pattern scholar and cultural spheres, is not linked to the contestations of power, extending the perennial role of education in keeping overall presence in countries' policy. And finally, the article warns that developing countries' mentality leads to a simplified perception of the internationalization as welfare growing strategy that intimately tends to consumerism. As well the publication exhibits the results of "STIPENDIUM" participants' feedback and observations.

\section{The categorical concept and comprehension}

Actually, the concept of IHE besides two generally admitted aspects of internal and external internationalization must include the borderomission elements and features. It undoubtedly has to promote the multiculturalism and to contribute to the elimination of borders in minds, approaches to studying and scientific research as well as the gap in goalsetting, decision-making way of thinking.

A simple, generic definition of internationalization is suggested by Maringe and Foskett (2010: 1) $)^{2}$, drawing on the work of Knight $(2004)^{3}$,

${ }^{2}$ Maringe F. \& Foskett N. (2010). Introduction: Globalization and universities. F. Maringe \& N. Foskett. Globalization and internationalization in higher education: theoretical, strategic and management perspectives. London/New York : Continuum International Publishing Group, 2010. P. 1-16.

Knight J. Internationalization remodeled: Definition, approaches, and rationales. Journal of Studies in International Education. 2004. № 8. P. 5-31. URL: http://dx.doi.org/10.1177/1028315303260832. 
de Wit $(1997)^{4}$ and Teichler (1996) ${ }^{5}$, that describes internationalization in the context of $\mathrm{HE}$ as 'the integration of an international or intercultural dimension into the tripartite mission of teaching, research and service functions'. In an often-cited definition of internationalization of higher education, Knight (1994, p. 21) states: "Internationalization is the process of integrating an international or intercultural dimension into the teaching, research, and service functions of an institution of higher learning" 6 . In a similar process-oriented definition, Altbach, Reisberg, \& Rumbley (2009, p. 23) note: "[internationalization refers to] specific policies and programs undertaken by governments, academic systems and institutions, and even individual departments" ". It is noteworthy that both authors pivot the definition on infusion of an approach to reach out and interrelate with other nations. Au contraire, the proliferation of globalization is described as "tentacular spread", internationalization is not a goal into itself, but means to an end: its value lies in enhancing pedagogy, research and innovation, and institutional engagement ${ }^{8}$. Middlehurst \& Woodfield (2007) have observed that internationalization has impacted higher education primarily in two ways: first, it has made the higher education sector more competitive, and secondly, it has driven institutions to devise policy prescriptions at the organizational level ${ }^{9}$. The former implies that higher education the world over is viewed as a global marketplace for international students, academics and research funds. Thus, institutions and education providers do not interact with each other in a random fashion; rather they engage in active competition.

${ }^{4}$ De Witt H. Internationalization of higher education: a conceptual framework. Internationalization of higher education in Asia Pacific countries / ed. J. Knight and H. de Wit. Amsterdam : European Association for International Education (EAIE), 1997.

${ }^{5}$ Teichler U. Comparative Higher Education. Potentials and Limits. Higher Education. 1996. № 32 (4). P. 431-465.

${ }^{6}$ Knight J. Internationalization: Elements and checkpoints. Canadian Bureau for International Education. Ottawa, Canada : CBIE, 1994.

7 Altbach P., Reisberg L. \& Rumbley L. Trends in Global Higher Education: Tracking an Academic Revolution. A Report Prepared for the UNESCO 2009 World Conference on Higher Education. Paris, France : UNESCO, 2009.

${ }^{8}$ Qiang Z. (2003). Internationalization of higher education: Towards a conceptual framework. Policy Futures in Education. 2003. № 1 (2).

${ }^{9}$ Middlehurst R. \& Woodfield S. Responding to the internationalization agenda: Implications for institutional strategy. 2007. URL: http://www.heacademy.ac.uk/ assets/documents/research/responding_to_the_internationalization_agenda_full_repo rt.pdf. 
The latter impact refers to the increasing range and complexity of activities undertaken by higher education institutions. These strategies might be limited in their goal to increasing international student enrolment, or these might be more comprehensive and aim to transform the entire ethos of the organization so it is internationalized across manifold dimensions. The IHE understanding adds competitive advantage driving institutions to incorporate the international element. This view perceives institutions to be partakers in the global marketplace of higher education as well as the multinational job market. Since globalization necessitates familiarity with cross cultural context it falls to higher education institutions to prepare the future workforce to meet the demands of global career. This view is born out of the interpretation that internationalization is part of an inevitable "academic entrepreneurialism" (Davies, 1992, as cited in Knight, 1994) ${ }^{10}$.

Hence, many ways understanding and interpretation of this process observed worldwide shape its different realization. There has in fact been a profound shift in the motivations for this increased mobility as new business goals have emerged: "the mobility of skilled workers in a globalized economy; the desire of higher education institutions to mobilize additional revenues or to increase their prestige and visibility on the national and international scenes; or the need for a better-educated workforce in emerging or aging economies", namely the desire of developing countries to attract the best talented and skilled labour in home research: in keeping with the knowledge economy logic, it aims to attract talented students and academics potentially able to serve to the host country's economics of knowledge and increase its research quality and competitiveness in the higher education and public administration sectors. Certainly, in this case the reason for internationalization is not cultural, but monetary: transnational education is often seen as a lever for economic development by governments, and as a competitive advantage for institutions. To overlap interests the organizations, links between academia, government and industry create conditions for new networks and dynamics with changing degrees of determinism over time.

Internationalization has also been characterized as a part of a political project, pushed in particular by the major international economic institutions, and aimed at transforming teaching practices to create a "new world space for higher education". Companies have already

${ }^{10}$ Knight J. Internationalization: Elements and checkpoints. Canadian Bureau for International Education. Ottawa, Canada : CBIE, 1994. 
become transnational or multinational, capital is more and more globalized. It is now up to individuals to become mobile and educational institutions to internationalize their practices, that is, to participate in cross-border commercial education. National view of the process is mostly bounded by this very restricted framework.

\section{Internationalization and the related processes}

The integration of higher education major factors includes economic, political, cultural, and pedagogical. Economic factors are related both to direct financial benefits (income from tuition fees for foreigners, language courses, internships, etc.), and indirect economic benefits, primarily an advanced training of high school graduates as a condition for lifelong education and economic progress. Political factors are defined by geopolitical interests, security issues, ideological influence, etc. Cultural factors emerged due to the importance of intercultural dialogue. Pedagogical factors influence the function and content of IHE. All these factors are closely intertwined and evolve.

By the end of the 1990s, overall internationalization and especially in the field of higher education was largely initiated and guided by political factors, above all by the desire to ensure the coexistence of different social systems, to strengthen cultural understanding and the political influence. Realities have changed, but the political processes in some countries and regions continue to shape and to adapt the requirements for educational processes. The world leading countries presence in the statebuilding processes in transitive societies through internationalization of the educational field determines their influence on the mass consciousness formation, the development of sciences, democratization as well as the ideological dominance. For instance, the conferences devoted to nowadays most pressing problems and, especially, their scientific exploration, are more and more frequently conducted on the basis of the leading universities in Asian and African countries. Except of creating an ideal platform for discussion, reflection and exchange, it made possible world progressive thoughts set up the prerequisites for further regional research trends and vectors.

The world community advocates that science should be out of politics. However, often in autocratic or semi-democratic regimes, science gets censored or sanctioned. The censorship in science appears particularly as regards the topic of scientific research, publicity or secrecy of the thesis defense, the publication of scientific and practical experiments results. As well if they sanction the country, they sanction 
small business, scientific field and sports, as repeatedly concerning Cuba or Russia.

IHE promotes unification of research requirements. In the post-Soviet space, the system of doctoral studies has been so stiff, corrupt and guided from above that in some fields of sciences became a valuable option for those elected who could afford postgraduate education. Thanks to the spread of higher education world quality standards and the requirements to the scientific works, the research and investigation projects have become truly scholastic, what is confirmed by the citation index, with significant scientific novelty and relevance, proven through the promulgation of scientific discourse on the subject. An application for the publication of the scientific research results in an international edition provides a kind of arbitration, which acts impartially within the accepted standards and requirements framework. To receive approval and to be admitted to publication in the editions included in bibliographic abstract databases is at the same time a high estimation at the supranational level of the scientist's contribution to the development of domestic science.

Besides, expanding the horizons for young scholars has made it compulsory to speak a foreign language, at least English. This, in turn, causes operational changes in public policy. In the light of the IHE process in developing countries and countries-aspirants to join the world scientific community on parity rights, the legislation in the sphere of education, science and language policy is being adapted. For example, in Ukraine, the requirements of time are reflected primarily in the Law of Ukraine "On Higher Education"" 1 . In particular, the Clause 2 of Art. 48 specifies that "In order to create conditions for international academic mobility, a higher education institution has the right to decide on the teaching of one or more disciplines in English and/or other foreign languages, while ensuring that the students of higher education acquire appropriate discipline in the state language". And the Law of Ukraine "On the Principles of State Language Policy" in Clause 12 of Article 20 allows educational establishments "to create classes, groups with studying in foreign languages" $"$. In addition to promoting the study of foreign languages, which makes Ukrainian specialists in various fields

${ }^{11}$ Law of Ukraine "On Higher Education”. URL: http://lpehea.in.ua/sites/default/ files/documents/law_of_ukraine_on_higher_education_en_2014.pdf.

12 Law of Ukraine "On the Principles of State Language Policy". URL: https://zakon.rada.gov.ua/laws/show/5029-17. 
competitive on the world labor market, this aspect brings financial benefits to educational institutions.

Among other things, the IHE path trotting may imply the creation of a "market-oriented high school", the rejection of universal academic training, the formation of knowledge and skills and capacity building as the instruments of action on the global education market. Likewise, the disappearance of political and ideological imbalances in the world, the proclamation of the universal values of socio-humanitarian development, environmental issues, the rapid growth of the Asia-Pacific region, China and Japan's increasing influence on the world economy, Korea's potential, the threshold states' achievements in nuclear weapon exploration indicate new priorities in education. Language challenges set trends and prospects in the labour market and business. Qualitative mastery of Asian, rare or exotic languages is possible only with native speakers, it revives diplomatic relations in the cultural and educational spheres, stimulates the opening of language courses and cultural centers. In consequence, while staying in another country, foreigners are assimilated with its cultural and social traditions learn the language of the host country and, as a result, contribute to its popularization at the regional and international level ${ }^{13}$.

Additionally, unified requirements and approaches to the organization of the learning process and the writing of scientific works introduced in international higher schools enrich the traditions of national universities in the world. Thus, for instance, joint programs are integrated, differentiated by degree (bachelor, master, doctoral, consecutive) and type of diploma (two (or more) diplomas, double diploma, joint certification). The IHE process besides students' and academic mobility includes the programs and curricula reforming and cooperation in the research field through different networks and associations. Open and distance learning, regional and foreign institutions cooperation to create strategic educational alliances, international division of labor and other activities are also among advantages.

Among the advantages of IHE are the pooling of resources, especially when they are so inaccessible, and avoiding of duplication and redundant

13 Yeravdekar, Vidya Rajiv \& Tiwari, Gauri. Internationalization of Higher Education and its Impact on Enhancing Corporate Competitiveness and Comparative Skill Formation. A Report Prepared for the International Relations Conference on India and Development Partnerships in Asia and Africa: Towards a New Paradigm (IRC-2013). Social and Behavioral Sciences. 2014. № 157. P. 203-209. 
copying of research topics along with the identification of educational projects. The given process also provides the possibility to push the limits of scientific search, preserve national identity while expanding the cultural horizons of trainees and trainers, influence the development of the country of origin and contribute to global economic and political stability.

Taking into account IHE characteristics and the position of the countries in educational services providing on the international market, OECD identifies educational services as import-oriented, import-export oriented and export-oriented types of HEI's orientation ${ }^{14}$. Moreover, the past decade leap in development of cross-border students' and scholars' exchange was a direct consequence of the fact that higher education in many countries acquires a mass character, the sphere of use of new information and communication technologies is expanding, the ideas of development of a knowledge-based economy, the internationalization of the labour market and the need for skilled labour have arisen and have been recognized. For this reason, internationalization of education demonstrates its effectiveness first due to the expansion of curricula and training of their students in foreign partner universities. The expansion of the university regional network for the effective resources use and the education and research quality improvement through the participation of students and teachers in knowledge sharing process go the next.

As practice shows, there have recently emerged new forms of internationalization, consisting in the institutions and programs transfer across the border. These forms of international supply of educational services, called the transnational education, are considered to be appropriate educational activities, in which students are not in the country where the higher education institution that issues diplomas is located. Indeed, the most characteristic forms of mobility of institutions are: the opening of foreign campuses by universities and/or commercial suppliers or the creation of a new higher education institution in which foreign capital takes part either alone or in partnership with a national university. Moreover, the mobility of educational programs includes distance education courses offered by foreign university; joint courses or

14 Vincent-Lancrin, Stйphan. «L'enseignement supйrieur transnational : tendances et perspectives d'avenir», dans OCDE (2011), L'enseignement supŭrieur a l'horizon 2030. Volume 2 : Mondialisation, La recherche et l'innovation dans l'enseignement, Йditions OCDE. P. 76. URL: http://dx.doi.org/10.1787/ 9789264075405-fr. 
programs offered by an internal university and its foreign partner institution; as well as franchising courses and programs. Hence, the procedure of IHE demonstrates the sustainable development and diversification.

Au contraire, internationalization at home is a concept which is a way to ensure that the majority of students who do not have the opportunity to study abroad, nevertheless, can take advantage of the effects of international influence. It means the introduction of educational programs/disciplines in foreign languages; integration of foreign visiting professors in the educational process; introduction of joint programs without obligatory or with short-term student mobility.

The causal link between the IHE and the globalization of world processes is actively traced in both directions. The actual problems of socio-political development determine the themes of scientific research, projects, international framework documents in education and stimulate the development of science in this direction. For example, energy conservation, environmental protection, the development of information and communication technologies, inclusive education, the elimination of gender inequality, racial discrimination, assistance to developing and the third world countries, provoked demands for scientific research, theoretical substantiation, development of practical steps solving these problems and joint strategies. To make scientific projects or thesis relevant and timely, they must contain the scientific novelty concerning the acutest current problems which means that they are constantly explored and examined worldwide. The internationalization of the educational space in a globalized world helps national, regional and institutional achievements on the above-mentioned topics reach the supranational level, gain global recognition and implementation.

\section{Internationalization in "STIPENDIUM" project data}

A simplified understanding of transnational cooperation between higher education institutions as export/import of brains, potential, theoretical and methodological achievements and data bases leads to a distortion of the very meaning and purposes of IHE and academic mobility. It turns in form of consumerism that is inherent in all process participants. The biggest challenge facing all the participants must be above all an ambition to defend branding in the "international reputation market" of higher education institutions despite the location and the status. For this reason the multiplication of global business education providers, the proliferation of international rankings require institutions 
to defend their reputation and brand. Hence the growing need for international projects funded by the EU programs automatically leads to appreciation and estimation from the international bodies' part.

As an illustration it's worthy to give an example of Jean Monnet educational module "State-international-public: European values and norms determining interdisciplinary university module (STIPENDIUM)" № 611217-EPP-1-2019-1-UAEPPJMO-MODULE being conducted at Borys Grinchenko Kyiv University (Kyiv, Ukraine) with the support of the Erasmus+ Programme of the European Union ${ }^{15}$. The objective of the module is to provide theoretical and practical training for $\mathrm{PhD}$ students in public administration, political science and international relations with topical coverage of common and actual threats and trends and the ways of their overcoming in Europe. In the framework of this educational module such activities are planned 1) to study the EU vision of weak/ failed State and the approaches to distance national-internationalsupranational and to preserve nation-Sate in united Europe; 2) to study the ways the EU manage with traditional values been now trapped, promote the most societal and adapt newly appearing ones; 3) to study internationalisation processes in different fields, e.g. higher education; 4) to determine societal values and vital steps to implement them in Ukraine; 5) to make up mechanisms for the most effective cooperation between the EU and Ukraine in different fields.

The main indicators of success are obtainable through next outcomes and impact: 1) the increase of awareness of European experience of public administration and the nation-State safeguarding; 2) dissemination of the case studies summaries among Ukrainian HEIs after the course completion; 3) steps to promote vital values within correlation Stateinternational-public among $\mathrm{PhD}$ students; 4) preparation of a package of recommendations to the Ukrainian state bodies concerning the internationalisation provision in different fields (after the course completion).

That is, the project implementers are put the task to combine the European experience with the Ukrainian educational and managerial potential for an effective and constructive capacity building for the future public administration officers, policymakers, diplomats, top-managers, authorities (the audience is up to 40 people).

Consequently, teaching is not the primary reason and goal of activities within the STIPENDIUM module. Nowadays Europe faces

${ }^{15}$ URL: http://stipendium.kubg.edu.ua/en/ 
many challenges and threats. The list of mind-bothering existing ones includes climate change, terrorism, peacekeeping, information wars, gender issue, economic and social issues etc. Not least important threats touch the State governance, social and humanistic values like future of education, skills and employment. Total transnationalization affects much the State "traditional" functions, the nation-State loses its monopoly in political and managerial decisions, the ability to control its own economy is getting considerably limited. Gradually, the nation-State leaves the sphere of world politics, the ruling groups lose the nation-state identity, as their political formula is no longer in harmony with the most prevalent feelings of the people. These trends create a background for a new (transnational) configuration of power to appear, to capture the erosion of the political subjectivity of the State, and to pass some of its functions to supranational, non-State actors. Transnational component is nowadays present in all spheres of social life and its damaging and threatening trends in one field can appear useful and progressive in another one. It's the matter of conscious and mature approaches to administering and governance. Europe has been trotting this way for a long time, while Ukraine is just starting. Our country suffers of poorly qualified politicians, educators, managers and public administrators in all the fields; the lack of will to adopt and to implement progressive European experience in educating new generation preserving societal values while trying some trans-internationalization. State policy of Ukraine is constantly aimed at achieving European standards. We are deeply convinced that before to elaborate and to implement right decisions at the highest level there is a need to educate a new generation of adequate policymakers and public administrators in the most vital spheres. Since there appeared a need to introduce educational module dealing specifically with EU studies and issues.

The module has been taught at Borys Grinchenko Kyiv University since October, 2019. It previews five educational courses and one distance learning course. For the period of implementation, the first course "Global societies, national states and identity" taught by the project coordinator, $\mathrm{PhD}$ in political science, assistance associate professor Tetiana Kostiuk got complete. By the time the project participants (scholars and $\mathrm{PhD}$ students) got acquainted with the actual EU policies in higher education, universities' social responsibility, societal values for the sustainable development of the region, integrative/ disintegrative trends, nation states challenges, weak/failed states theories and so on. To demonstrate acquired awareness the participants were 
asked to elaborate the list of recommendations to the state bodies on the issues related to the course and project title and thematic plan. The same task will be put after each of the courses of the given module, and then the recommendations will be moderated, edited and disseminated.

The overall analysis of details related to IHE and the results of the first stage of the "STIPENDIUM" module conducted by Scientific Research Laboratory of Internationalization of Higher Education of Borys Grinchenko Kyiv University reflected in this article makes it possible to compose a list of recommendations for further national IHE Strategy and public administration bodies to take into account in domestic and foreign policy of Ukraine.

1. To establish Administrative Board to Boost International Cooperation in the Field of Education

With the aim of sustainable development of higher education, the government should participate thoroughly in every activity related to the international aspect of education. It can be demonstrated, for example, by merging the publicity sources for higher education and negotiating acknowledgement of higher education certificate, the enrollment of foreign students and establishment of agencies abroad. The government should establish Administrative Board to conduct negotiations at the highest level to reach agreement on key issues of interstate cooperation in the field of education and science. But it will work only with State or municipal educational institutions, meanwhile there are private educational institutions in form of Private Joint Stock Companies. In this case Government must adopt legal regulatory acts controlling relations with foreign students and foreign educational establishments.

\section{Reputation Molding}

The ranking of the world universities previews some essential points and standards which are crucial while evaluating HEIs. These are personal scholars' achievements (scientific degree, citation rate, inventions, patents, foreign languages, lectures abroad) and general university's rate determined by the level of accreditation, the indicators of the educational services quality, the number of specialties, licenses, the percentage of admission to the Master's degree among graduates, the quantity of postgraduates students, the employment of graduates, participation in international projects and consortiums, the number of solely won projects. However, not many Ukrainian universities can compete with the developed countries' universities. One of the obstacles is an inadequate language policy, not all HEIs propose even English language training courses or studying modules/courses in English, 
although English is a big advantage attracting foreign students. Moreover, nowadays linguistic trend is Chinese language. It cannot be considered similarly as English as the language of international communication, but growing interest to China and the quantity of Chinese will soon make people all over the world study their language. Introducing Chinese would be a stepping stone to higher rates and reputation.

\section{Communicative Policy}

The presence of foreign students brings higher education institutions not only economic benefits. First and foremost, it adds to popularity, which, in its turn, affects the total number of students, the infrastructure of the university, stimulates for constant renewal and development. Ukrainian universities should strive not to lose feedback from students and graduates. International universities are widely practicing the creation of alumni clubs to combine the dissemination of information about the institution and its policies and communication opportunities. Thus, the university unites young people from all over the world not only for the period of their studies, it becomes an integral factor for a long time, stimulating a constructive exchange of thoughts and experiences, mutual assistance and intercultural dialogue. Ukraine should adopt this experience of communication building and actively use it as soon as possible, and then the experience and assistance of outstanding graduates will best promote the popularity and intensification of international contacts.

\section{To minimize Brain Drain}

Brain drain, intensive competitiveness on the world education market and disproportion of funds cause troubles for the international communication and cooperation, and is the worst result of the internationalization of higher education process. Brain drain is clearly observed in the developing countries, Ukraine is not an exception. Many scholars try their forces in grant application, win them and join the international scientific community while delivering lectures abroad in partner HEI. Developed countries try to create all favorable conditions for personal and professional development of gifted and hard-working scientists and researchers. The most important factors for successful career building in educational field are appropriate attitude, working conditions and funds. The State policymakers must realize that the higher quality education is, the more competitive country is on the world market. Since Ukraine has joined the European Union, WTO, the educational services have got to be the world standards as they are now 
open to the world. To raise competitiveness and to attract brainy people to the country the government must improve their working conditions, such as human resource management system, promotion system, guaranty access to continuous lifelong studying, supporting the educators' rights. The development of international ties in the field of education, internationalization of approaches and demands can help it on condition that the government put it forward and augment the investment. Consequently, not only home intellectuals will always return, but the overseas students can be attracted and stay in our country.

\section{Encourage the Internationalization of Higher Education}

IHE means not only active international communication and cooperation, but also elimination of borders in approaches and demands to the educational process, scientific works and researches. It previews also an establishment of the international scholar environment and infrastructure implying international campuses and facilities for the students as well as scientific activities for the academicians like consulting, exhibitions, conferences, workshops, publications. To encourage the process of internationalization in HEIs it is recommended to establish some system of remuneration and reward for the most active students and staff; to coordinate and encourage international departments to cooperate with world educational institutions; to stimulate high quality academic writing; to invite outstanding lecturers; to set up exchange of teaching personnel and students.

\section{CONCLUSIONS}

Education is only one link in the national development strategy, which determines the country's ranking in different fields, its priority and authority in the world. Qualitative education with an emphasis on patriotic national education is at the basis of the general policy of the state, its socio-humanitarian component is aimed at preserving the national identity with the parallel intensification of the process of sectoral implementation of innovations and world trends.

The internationalization of higher education is a process that has become a manifestation of globalization in science and education. This tendency is to unify standards, specialties, educational qualification levels, curricula and programs, requirements, evaluation systems; it is a program of student and academic exchanges, double diplomas; it is an academic dialogue, the dissemination of experience. But among others there is the issue of the economic development of educational institutions, based on the opening of language courses, summer camps 
and preparatory faculties. It is also a matter of political influence, and even expansion. For example, sponsoring educational institutions or educational/research projects, creating enabling environments, programs, brain drain grants, language policy, co-financing research, creates a donor country with all the conditions for political presence in the domestic policy of the recipient country. This should be remembered by the countries of the former USSR, which in their search for a development vector often hesitate between Asian, or European, areas of cooperation and funding sources.

Ukraine is always a progressive state, which in many spheres leads the countries with advanced technologies. Education is not an exception. Ukrainian scholars and educators are known all over the world, their experience and development are highly appreciated; innovations have been recognized and sponsored by numerous projects and grants, either European or American. Lack of State financing and public funding leads to the fact that the behavior of Ukrainian higher educational institutions is adaptive, they turn into grant-eaters, lose the renown of the advanced institutions of higher education in their field. In order to stop such destructive tendencies, to bring higher education in Ukraine to a qualitatively new level, to retain the status of leaders in their fields by Ukrainian higher education institutions, it is necessary to carry out certain reforms.

\section{SUMMARY}

Nowadays many societies and countries are becoming more and more focused on themselves as the backlash against globalization. On the contrary educational field strives to unification and generalization. The main vectors on which the modern international component of higher education develops is, firstly, the unification of scientific and pedagogical efforts and resources, and secondly, academic mobility and grant writing. The greatest success is observed in educational field demonstrating harmonic combination of outstanding national traditions and scientific schools' approaches with the world trend toward internationalisation. It made basis for the Jean Monnet educational module "STIPENDIUM" № 611217-EPP-1-2019-1-UAEPPJMOMODULE with the support of the Erasmus+ Programme of the European Union. The paper deals with the issues how to make scholars and researchers work out common demands, approaches and create background with the sound feedback in co-working with the public administration bodies. State policy of Ukraine, including educational 
field, is constantly aimed at achieving world standards for the sake of joining democratic developed countries and shared future in a fractured world.

\section{REFERENCES}

1. Altbach P., Reisberg L. \& Rumbley L. Trends in Global Higher Education: Tracking an Academic Revolution. A Report Prepared for the UNESCO 2009 World Conference on Higher Education. Paris, France : UNESCO, 2009.

2. Bhandari, Rajika. HSBC Global Report "The value of Education: Higher and Higher". URL: file:///C:/Users/adm/Downloads/ 170628-thevalue-of-education-higher-and-higher-global-report.pdf.

3. HORIZON 2020 in full swing - Three Years On-Key facts and figures 2014-2016. URL: https://ec.europa.eu/programmes/horizon2020/ sites/horizon2020/files/h2020_threeyearson_a4_horizontal_2018_web_w ith_id.pdf.

4. Knight J. Internationalization: Elements and checkpoints. Canadian Bureau for International Education. Ottawa, Canada : CBIE, 1994.

5. Knight J. Internationalization of higher education: a conceptual framework. In Internationalization of higher education in Asia Pacific countries, ed. J. Knight and H. de Wit. Amsterdam : EAIE, 1997.

6. Knight J. Internationalization remodeled: Definition, approaches, and rationales. Journal of Studies in International Education. 2004 № 8. P. 5-31.

7. Law of Ukraine "On Higher Education". URL: http://lpehea.in.ua/sites/default/files/documents/law_of_ukraine_on_high er_education_en_2014.pdf.

8. Law of Ukraine "On the Principles of State Language Policy". URL: https://zakon.rada.gov.ua/laws/show/5029-17.

9. Maringe F. \& Foskett N. (2010). Introduction: Globalization and universities. F. Maringe \& N. Foskett. Globalization and internationalization in higher education: theoretical, strategic and management perspectives. London/New York : Continuum International Publishing Group, 2010. P. 1-16.

10. Middlehurst R. \& Woodfield S. Responding to the internationalization agenda: Implications for institutional strategy. 2007. URL: http://www.heacademy.ac.uk/assets/documents/research/ responding_to_the_internationalization_agenda_full_report.pdf. 
11. Qiang Z. Internationalization of higher education: Towards a conceptual framework. Policy Futures in Education. 2003. № 1 (2).

12. Survey on the Results of International Mobility conducted. Prepared by Scientific Research Laboratory of Internalization of Higher Education of Borys Grinchenko Kyiv University. URL: https://docs.google.com/forms/d/1 va1mUgVn2ENPfrhzSbTpLmUwi8yiI TmR_fy6WZjAxOA/edit\#responses.

13. Teichler U. Comparative Higher Education. Potentials and Limits. Higher Education. 1996. № 32 (4). P. 431-465.

14. Vincent-Lancrin, Stйphan. "L'enseignement supйrieur transnational : tendances et perspectives d'avenir", dans OCDE (2011), L'enseignement supŭrieur a l'horizon 2030 - Volume 2 : Mondialisation, La recherche et l'innovation dans l'enseignement, Йditions OCDE. P. 76. URL: http://dx.doi.org/10.1787/9789264075405-fr.

15. Yeravdekar, Vidya Rajiv \& Tiwari, Gauri. Internationalization of Higher Education and its Impact on Enhancing Corporate Competitiveness and Comparative Skill Formation. A Report Prepared for the International Relations Conference on India and Development Partnerships in Asia and Africa: Towards a New Paradigm (IRC-2013). Social and Behavioral Sciences. 2014. № 157. P. 203-209.

\section{Information about the author:} Kostiuk T. O.,

$\mathrm{PhD}$ in Political Science, Associate Professor, Senior Research Fellow of SRL of Internationalization of Higher Education Borys Grinchenko Kyiv University 18/2, Bulvarno-Kudryavska Str., Kyiv, 04053, Ukraine 